\title{
CHEMICAL AND PHENOTYPIC DIVERSITY OF MEXICAN PLUMS (Spondias purpurea L.) FROM THE STATES OF GUERRERO AND MORELOS, MEXICO ${ }^{1}$
}

\author{
YANIK IXCHEL MALDONADO ASTUDILLO ${ }^{2,5}$, IRÁN ALIA TEJACAL ${ }^{2}$, \\ ALBERTO CARLOS NÚÑEZ-COLIIN ${ }^{3}$, JAVIER JIMÉNEZ HERNÁNDEZ ${ }^{4,5}$, \\ VÍCTOR LÓPEZ MARTÍNEZ²
}

\begin{abstract}
Fruits from 86 ecotypes of Mexican plum were harvested from the states of Guerrero and Morelos during the dry season. Of these, 22 were wild ecotypes and 64 were cultivated varieties. Among the variables measured, those with the highest variation coefficients were color, flavor, and mass ( $>45 \%)$, highlighting the presence of considerable intra-species variability. Cluster analysis separated the 86 accessions into 5 groups, mainly on the basis of color, flavor, length, and mass. Members from the first three groups had red (Group I), yellow (Group II), or purple (Group III) epicarps and higher values of mass (12.2-16 g), length (29.6-33.9 mm), pulp yield (68.8-71.9\%), TSS (11.16-11.52 ${ }^{\circ}$ Brix) and flavor index (14.5-18.3), making them suitable for horticultural use and fresh consumption. The wild ecotypes clustered in the remaining two groups and consisted of small (23.2-27.7 mm, 5.5-8.2 g) red drupes of differing hues. The cherry-red color of the fruits from Group IV suggests possible antioxidant properties due to the presence of polyphenolic pigments which could be of interest to the pharmaceutical and cosmetic industries. Finally, fruits from Group V, being the most acidic ( $\mathrm{pH}$ 2.7, 2.1\% acidity), might be better suited for the preparation of pickled products and sauces. Index terms: Quality, canonical discriminant analysis, cluster analysis, genetic diversity, underutilized crops.

\section{DIVERSIDADE QUÍMICA E FENOTÍPICA DAS AMEIXAS MEXICANAS (Spondias purpurea L.) DOS ESTADOS DE GUERRERO E MORELOS, MÉXICO}

\begin{abstract}
RESUMO - Frutos de 86 ecotipos de ameixa mexicana foram colhidos dos estados de Guerrero e Morelos durante a estação seca. Destes frutos, 22 foram ecotipos selvagens e 64 variedades cultivadas. Entre as variáveis medidas, aquelas com os maiores coeficientes de variação foram cor, sabor e massa (>45\%), destacando-se a presença de considerável variabilidade intra-espécies. A análise de clusters separou os 86 acessos em 5 grupos, principalmente com base na cor, sabor, comprimento e massa. Os membros dos três primeiros grupos apresentaram epicarpos vermelhos (Grupo I), amarela (Grupo II) ou púrpura (Grupo III) e maiores valores de massa (12,2-16 g), comprimento (29,6-33,9 mm), rendimento de polpa (68,8 -71,9\%), $\operatorname{TSS}\left(11,16-11,52^{\circ}\right.$ Brix $)$ e índice de aroma $(14,5-18,3)$, tornando-os adequados para uso hortícola e consumo fresco. Os ecotipos selvagens se agruparam nos restantes dois grupos e consistiram em pequenas drupas vermelhas $(23,2-27,7 \mathrm{~mm}, 5,5-8,2 \mathrm{~g})$ de diferentes tonalidades. A cor vermelha cereja dos frutos do Grupo IV sugere possíveis propriedades antioxidantes devido à presença de pigmentos polifenólicos que poderiam ser de interesse para as indústrias farmacêutica e cosmética. Por fim, os frutos do Grupo V, sendo os mais ácidos (pH 2,7-2,1\% de acidez), podendo ser mais adequados para a preparação de conservas e molhos.

Termos para indexação: Qualidade, análise discriminante canônica, análise de agrupamento, diversidade genética, culturas subutilizadas.
\end{abstract}

\footnotetext{
1(Paper 252-15). Received November 03, 2015. Accepted June 06, 2016.

${ }^{2}$ Faculty of Agricultural and Livestock Sciences, Universidad Autónoma del Estado de Morelos, Av. Universidad 1001, Cuernavaca, Morelos, C.P. 62210, México. (52) 7771345402. E-mails: ijac96@yahoo.com.mx; vilomar.leo@gmail.com

${ }^{3}$ Program of Biotechnology engineering. University of Guanajuato, Mutualismo \# 303 Esq. Extension Rio Lerma, Col La Suiza. Celaya, Guanajuato. México. CP. 38060. (52) 46159859 22. E-mail: lit007a@gmail.com

${ }^{4}$ Chemical and Biological Sciences Faculty. Universidad Autónoma de Guerrero. Av. Lázaro Cárdenas s/n. Ciudad Universitaria,Chilpancingo de los Bravo, Guerrero. CP. 39070, México. (52) 74747255 03. E-mails: yaixma@gmail.com; jjimenez@ uagro.mx

${ }^{5}$ Postgraduate Studies and Research Unit. Universidad Autónoma de Guerrero. Calle Pino s/n col. El Roble, Acapulco, Guerrero. CP. 39460, México. (52) (744) 48777 40. E-mal: jjimenez@uagro.mx; yaixma@gmail.com
} 


\section{INTRODUCTION}

Spondias purpurea (Anacardiaceae) is a tropical species whose physiological, anatomical, and agronomic plasticity allows it to grow in soils that would be otherwise unsuitable for conventional agriculture, as well as at a wide range of altitudes and in different climates. Mexican plums are drupes of different shapes (oblong, round or oval), lengths (20-50 mm), masses (4-43 g) and colors (yellow, red, orange, purple), with thick fibrous endocarps and mesocarps of a palatable taste and flavor (LEON et al., 1990; MALDONADO-ASTUDILLO et al., 2014). They are known as 'jocotes', 'jobos', or 'abales' in different regions of Mexico (RUENES et al., 2010) and have traditionally been consumed since prehispanic times (AVITIA et al., 2000). Mexican plums can be classified as either dry-season (April to June) or wet-season (September to December) fruits based on their time of fruiting (LEON et al., 1990), although a third, intermediate category also exists that is considered a 'hybrid' between the other two (AVITIA et al., 2000). Miller and Knouft (2006) mentioned the existence of both wild and cultivated populations of $S$. purpurea, with the former constituting the ancestral progenitors of the latter. Cultivated populations differ from the ancestral varieties in terms of morphology, flavor, and mode of reproduction as a result of the genetic changes that occurred during the process of domestication and artificial selection. There are two known centers of origin in Mesoamerica for this species: one comprising the western portion of central Mexico, and the other spanning a region that includes both southern Mexico and Central America (MILLER et al., 2006; NETO el al., 2013). S. purpurea can be found distributed in the deciduous and semideciduous lowland forests of tropical America, from the western coast and the southeast regions of Mexico (AVITIA et al., 2000), to Central America (POPENOE, 1979), Peru, and Brazil (AVITIA et al., 2000), and has even been introduced into certain regions of Africa and Asia (KOSTERMANS, 1991; DUVALL, 2006). In Mexico, it can be found in 21 of the 31 federated states, principally in Chiapas, Puebla, Sinaloa, Jalisco, Guerrero, Veracruz, Nayarit, and Yucatan (AVITIA et al., 2000).

Information concerning the different genotypes is scarce because, in the wild, S. purpurea tends to grow in remote, difficultly accessed areas, and its cultivation has largely been based on the use of informal agricultural practices (backyard gardens, hedges and small farms). In addition, few studies specifically address the diversity of genotypes of $S$. purpurea. Nava and Uscanga (1979) analyzed the chemical composition of 12 ecotypes from Veracruz and concluded that $S$. purpurea had a nutritional value that was comparable to those of other fruit like the orange, mango, papaya, and pineapple; Vargas et al. (2011) characterized four Mexican plum accessions from Tabasco and observed a noticeable variation in the morphology of leaves, flowers and fruits as well as in their respective phenological stages; Ruenes et al. (2010) conducted ethnobotanical studies using 10 fruit accessions from Yucatán that were used by local farm families for food, fodder, and medicinal purposes. Ramirez et al. (2008) highlighted the agronomic and ecological importance of the species: they characterized 12 fruit accessions from Colima, Nayarit, and Jalisco, concluding that, overall, cultivated varieties have better commercial and nutritional characteristics compared to wild populations. A wide diversity of Mexican plum ecotypes from the states of Guerrero and Morelos has been reported (PEREZ et al., 2008; ALIA et al., 2012; MALDONADO-ASTUDILLO et al., 2014) where $S$. purpurea can be found growing in the wild or at small-scale or commercial orchards, yet little has been documented in terms of the physical, chemical, and morphological characteristics (ALIA et al., 2012).

The aim of this study therefore, is to provide information on the diversity of dry season Mexican plum fruits originating from the Mexican states of Guerrero and Morelos, with a special focus on their morphological, chemical, and commercial quality characteristics.

\section{MATERIALS AND METHODS}

Fruit sampling. A total of 86 samplings were performed from April to June 2012 at 11 municipalities located in the Central, Acapulco, and Northern regions of the state of Guerrero as well as at 7 other municipalities in southern Morelos, Mexico (Table 1). The coordinates and altitude of each sampling location were determined with the use of a Garmin eTrex ${ }^{\circledR}$ global positioning system, while temperature and relative humidity $(\mathrm{RH})$ were measured using a RadioShack $\AA$ hygro-thermometer. For each tree that was sampled, a total of 20 fruits were collected, all of which were visually inspected and verified to be healthy, free from physical damage or pathogen infestation, and at a stage of development that corresponded to commercial maturity. These were then transferred to the Agricultural Production laboratory at the Autonomous University of the State of Morelos (in Mexico) for further analysis. 
Evaluated variables. Upon arrival, the fruits were stored at room temperature $(20 \pm 2$ ${ }^{\circ} \mathrm{C} ; 60 \% \mathrm{RH}$ ) for $12 \mathrm{~h}$ in order to remove the field heat; subsequently, they were washed with chlorinated water and dried using absorbent paper. The mass of each fruit fraction (epicarp, mesocarp and endocarp) was then measured using a precision balance (OHAUS ${ }^{\circledR}$, USA) while the longitudinal (LD) and transverse diameters (TD) of the fruit and its endocarp, as well as the length of the pedicel, were measured using a digital vernier (TRUPER $®$ ). With the diameter values obtained, a shape index of both fruit $\left(\mathrm{SI}_{\mathrm{F}}\right)$ and endocarp $\left(\mathrm{SI}_{\mathrm{E}}\right)$ was calculated separately using the LD/TD ratio. Epicarp color (lightness, $\mathrm{L}^{*}$; chroma $\mathrm{C}^{*}$; and hue angle, h) was measured on the two opposite sides of a cross section of each fruit with the use of an X-Rite spectrophotometer (mod. 3690) (McGuire, 1992). Total soluble solids (TSS), titratable acidity (TA) and the fruit's flavor index (FI) were determined as described by Alia et al. (2012) while pH was measured in the same aqueous solution used for determining the TA using the potentiometric method (981.12) reported by AOAC (2002). Firmness was measured using a CHATILLON ${ }^{\circledR}$ digital penetrometer (John Chatillon \& Sons, New York, USA) equipped with a conical tip (0.6 $\mathrm{mm}$ height $\mathrm{x} 0.7 \mathrm{~mm}$ base) by measuring the force required to penetrate $0.5 \mathrm{~cm}$ into the fruit's surface. The pulp yield (PY), expressed as a percentage (\%), was calculated from the ratio between the mesocarp mass and the total mass of the fruit.

Statistical analysis. The basic unit of characterization (BUC) consisted of a single ecotype, with one fruit comprising an experimental unit. Ten replicates were made for each measurement of color, size, mass, and pulp yield, whereas six replicates were made in the case of firmness. For all chemical evaluated parameters (TSS, TA and $\mathrm{pH})$, three replicates with two fruits comprising an experimental unit, were used. The data were processes by several multivariate analyses based on Nuñez-Colin and Escobedo-Lopez (2014), where the first step was to apply a cluster analysis using the method of Ward (Ward, 1963). From the groups formed of this analysis, a Discriminant Canonical Analysis (DCA) was done. DCA aims to corroborate if each member belonged of the group where it was grouping by the resubstitution test. Besides, to compare among groups by the Mahalanobis distance test. In addition, to know the main variables to distinguish the groups by canonical analysis as well as the projection of the BUC in the first three canonical roots, which was draw the graphic using SigmaPlot $\AA$ version 10 . Furthermore, to know the significance differences between groups in the first three canonical roots, a modified MANOVA and Tukey tests was applied based on Johnson (1998). All analyses were calculated using SAS Software v. 8 (SAS Institute 1999).

\section{RESULTS AND DISCUSSION}

From the 86 ecotypes of Mexican plum that were harvested, 22 constituted wild types while the rest (64) represented cultivated varieties. From the latter, 54 originated from the state of Guerrero and 32 from the state of Morelos (Table 1). The altitudes where they were harvested ranged from $121 \mathrm{~m}$ (Acapulco, Guerrero) to 1,244 m (Taxco, Guerrero). The average temperature of these sampling locations was $36^{\circ} \mathrm{C}$, with a minimum of $25.7^{\circ} \mathrm{C}(\mathrm{RH}>80 \%)$ and a maximum of $43{ }^{\circ} \mathrm{C}(\mathrm{RH}<20 \%)$.

According to the previous reports, natural populations of $S$. purpurea can be found at altitudes that range from sea level to $2000 \mathrm{~m}$. Nevertheless, Ramirez et al. (2008) in Mexico and Otzoy et al. (2005) in Guatemala point out that the greatest abundance of this species occurs between 0 and $60 \mathrm{~m}$. In the state of Guerrero (Mexico), the municipalities of Tlapehuala, Cocula, Teloloapan, Quechultenango, and San Marcos constitute the main agricultural regions for the production of Mexican plum, while in the nearby state of Morelos they include the municipalities of Cuernavaca, Tepoztlan, Puente de Ixtla, and Totolapan (AVITIA et al., 2000).

\section{statistics \\ Description of characteristics and basic}

Hue angle was the color parameter that presented the greatest variation across all fruits analyzed $(\mathrm{CV}=45.16 \%)$ (Table 2$)$. The maximum values of $\mathrm{L}^{*}$ and $\mathrm{C}^{*}$ were found in the yellow ecotypes M02 and M27 while the maximum values of h occurred in the red ecotype M024. Conversely, the ecotype with the lowest values of $L^{*}, C^{*}$, and $\mathrm{h}$ was $\mathrm{G} 19$, a purple-colored fruit from the state of Guerrero.

In terms of mass and length, the fruits with the lowest values ( $3 \mathrm{~g}$ and $16 \mathrm{~mm}$, repectively) were those of ecotypes G54 and G53 - two wild, orangecolored varieties also found in the state of Guerrero. On the other hand, ecotype G05 - known as 'Costeña' or 'Ciruela china' -had the maximum values of mass and length (36 g, $45 \mathrm{~mm}$ ) (Table 2).

The variation of color that was observed among the fruits of $S$. purpurea, particularly in 
terms of hue angle $(\mathrm{h})$, was similar $(46.4 \% \mathrm{CV})$ to the value that was reported by Alia et al. (2012) and Maldonado-Astudillo et al. (2014). After analyzing a number of red, orange, and yellow varieties of $S$. purpurea, Perez et al. (2008) concluded that color can be a useful variable in the characterization of ecotypes for selection and breeding. Ramirez et al. (2008) described the presence of red, dark red, yellow, yellow-orange, and green colors in the fruits of Mexican plum. Similarly, Ruenes et al. (2010) reported red, dark red, orange, yellow, and purple colors while Alia et al. (2012) observed green $(\mathrm{h}=$ 105.4), yellow $(\mathrm{h}=80-90)$, orange $(50-70 \mathrm{~h})$ and red $(\mathrm{h}=15.4)$ colors in the epicarp of the fruits. The epidermal color in $S$. purpurea is closely tied to the metabolism of carotenoid pigments (yellow-red), polyphenols (red-blue) and chlorophyll (green), which in turn, confer antioxidant properties upon the fruit. The antioxidant capacity varies according to the type of phenolic compound that is present (e.g. flavonoids), as well as in response to changes in the content of carotenoids, vitamin $\mathrm{C}$, and vitamin $\mathrm{E}$. This composition can, in turn, be influenced by the type of species, variety, geographical origin, edaphological conditions, state of maturity, etc. (SILVA et al., 2012; RIBEIRO et al., 2013). However, these characteristics have been evaluated mainly in fruits of $S$. purpurea originating from Brazil (ALMEIDA et al., 2011; SILVA et al., 2012; GREGORIS et al., 2013; RIBEIRO et al., 2013), Costa Rica (MONGE et al., 2011; ENGELS et al., 2012), and Panama (MURILLO et al., 2010, 2012). Given the diversity of colors that characterize Mexican varieties, it is important to determine the composition and activity of antioxidant compounds present in the fruits of $S$. purpurea as they can constitute important sources of such compounds for the inhabitants of the regions where they are cultivated.

Mass and length are characteristics that have been evaluated in $S$. purpurea ecotypes from the Mexican states of Guerrero, Morelos, and Chiapas. Perez et al. (2008) reported values for mass that ranged from 7.22 to $33.07 \mathrm{~g}$, while Alia et al. (2012) and Maldonado-Astudillo et al. (2014) reported values from 4.0 to $43.2 \mathrm{~g}$. Vargas et al. (2011) reported a range between 15.5 and $24.9 \mathrm{~g}$ in fruit from Tabasco, while Nava and Uscanga (1979) described variations between 8.7 and $37 \mathrm{~g}$ in ecotypes from Veracruz. Finally, in the states of Colima, Jalisco, and Nayarit (also in Mexico) Ramirez et al. (2008) reported a variation in the masses of fruits that ranged from 6 to $36 \mathrm{~g}$.

In other countries such as Brazil, Lira Junior et al. (2010) described values for mass that oscillated between 9.6 and $10.6 \mathrm{~g}$ whereas in Ecuador, Macia and Barfod (2000) examined fruit with masses between 9.0 and $18 \mathrm{~g}$. In terms of length, Perez et al. (2008) reported values that ranged from 24.74 to $36.54 \mathrm{~mm}$, whereas, Lira Junior et al. (2010) reported values from 30.77 to $34.17 \mathrm{~mm}$, as well as shape indices (DL/DT) that varied from 1.35 to 1.41 and which corresponded to ovate fruits. Such results differed from those reported by Ramirez et al. (2008), who described globular forms (DL/DT of 0.74 to 0.91 ), as well as the values reported by Filgueiras et al. (2001) who always observed oblong fruits (DL/DT between 1.33 and 1.35). Similar fruits were observed by Nava and Uscanga (1979), who described 4 different variants of rounded shapes. The shape of the fruits collected in this study were varied (DL/DT between 0.74 and 1.58) despite having a low coefficient of variation (10.01). According to Bosco et al. (1999), the fruits of Spondias may be classified as large $(>15 \mathrm{~g})$, medium $(12-15 \mathrm{~g})$, or small $(<12 \mathrm{~g})$ based on size, and as round (DL / DT $<1$ ) or elongated (DL / DT > 1) based on shape. However, Chitarra and Chitarra (2005) specify that fruits with DL/DT values closer to 1 (i.e. round) are preferred for commercial purposes as their shape greatly facilitates cleaning and processing operations.

Additionally, the pulp yield in S. purpurea is not significantly influenced by either the mass or the size of the fruit (PINTO et al., 2003). In this study, the pulp yield varied from $31.91 \%$ (in the ecotype 'silvestre') to $81.65 \%$ (in the ecotype 'Chilera') (Table 2). Similar values have been reported by Filgueiras et al. (2001), Lira Junior et al. (2010), Nava and Uscanga (1979), Ramírez et al. (2008), and Vargas et al. (2012), with values that range from 65 to $86 \%$. The pulp yield in $S$. mombin varies from 27.4 to $61.8 \%$, and the mass of fruits from 6 to 18 $\mathrm{g}$ (BOSCO et al., 1999; PINTO et al., 2003). On the other hand, the yield of hybrid genotypes ( $S$. mombin x $S$. tuberosa) varies from 69.7 to $85.63 \%$ with mass values that range from 18 to $24 \mathrm{~g}$ in fruits with rounded or oblong shapes (DL / DT of 1.14 to 1.39) (LIRA JUNIOR et al., 2005; SANTOS et al., 2010).

The flavor index (FI) varied from 2.76 (ecotype M22) to 32.74 (ecotype G04). The TSS content of fruits varied from 6 to $17^{\circ} \mathrm{Brix}$ - values that correspond to the ecotypes G52 ("Amarilla de Chile') and M25 ('Conservera') respectively. This range was similar to the one that was reported by Pérez et al. (2008) (12.47 to $17.43^{\circ}$ Brix), and Nava and Uscanga (1979) (13 to $18^{\circ}$ Brix). Similarly, Alia et al. (2012) measured values that ranged from 3.2 to $17.3{ }^{\circ} \mathrm{Brix}$, together with FI values that fluctuated between 3.0 and 63.2. Ramirez et al. (2008) recorded 
values from 7 to $15.6^{\circ}$ Brix, reporting additionally that a higher content of TSS was present in cultivated varieties of Mexican plum $\left(>12^{\circ}\right.$ Brix $)$ compared to wild populations. Meanwhile, Ruenes et al. (2010) observed a TSS interval that ranged from 12.97 to $21.28{ }^{\circ} \mathrm{Brix}$; they concluded that sweetness, pulp content, and epicarp thickness are important characteristics for the cultivation and marketing of Mexican plum varieties originating from Yucatan.

Germoplasm characterization Cluster analysis produced 5 different groupings using a distance coefficient of 0.045 (Fig 1). Group 1 (17 fruit accessions or $19.7 \%$ of the total) consisted of red $(h=31.7)$, round plums of an average mass and length, with a low proportion of endocarp and a high pulp yield (Table 3 ). Group II, containing the largest number of accessions (22, corresponding to $25.6 \%$ of the total), consisted of predominantly oblong, yellow fruit $(\mathrm{h}=68.6)$ with relatively high values of lightness $\left(L^{*}=55.7\right)$ and chromaticity $\left(C^{*}=45.9\right)$, average mass, and a high pulp yield (68.8\%). Group 3 (14 fruit accessions or $16.3 \%$ of the total) consisted of oblong drupes of a red-purple color $(\mathrm{h}=27.1)$ at commercial maturity, and which had the largest values of mass, length, firmness, pulp yield, and flavor index (Table 3 ). The wild ecotypes, on the other hand, clustered in the remaining two groups and consisted of small fruits with low pulp yields and a low content of TSS. Specifically, Group IV (13 fruit accessions or 15.1\% of the total) consisted of oblong fruits of a red-purple color $(\mathrm{h}=27.7)$, while Group V (20 fruit accessions or $23.3 \%$ of the total) consisted of ovate, acidic fruit of an orange or pale red color $(\mathrm{h}=35.6)$ and with a low FI (Table 3).

Canonical discriminant analysis determined that the first three roots (CR1, 2, and 3) accounted for $95.43 \%$ of the total variance (Table 4 ). The first root (CR1) accounted for $47.36 \%$ and was related to the $\mathrm{h}$ and $\mathrm{L}^{*}$ parameters of fruit color (hue angle and lightness, respectively) (Table 5). The second canonical root (CR2) accounted for $35.77 \%$ of the total variance and was mainly related to acidity. Lastly, the third canonical root (CR3) was related to fruit firmness.

In the three-dimensional graph (Fig 2) Group II is clearly separated from the rest of the groups along CR1 while Group 5 is visibly separated along CR2. Groups I, III, and IV appear to be the closest, albeit with differences in these components according to the Tukey test (Table 6). Specifically, Groups I and III did not present any significant differences along CR1, just as no differences were detected between Groups I and IV along CR2 and Groups III and IV along CR3 (Table 6).
In a preliminary study involving 46 fruit accessions from southern Morelos, 13 from northern Guerrero, and 8 from Chiapas (all in Mexico), Alia et al. (2012) obtained 7 different grouping of Mexican plums by taking into account 10 quantitative variables and using the hierarchical clustering method UPGMA. Specifically, the yellow-orange plums that originated from Chiapas clustered inside 3 different groups: Group I (which consisted of round-shaped fruits), Group II (consisting of elliptical fruits), and Group VII (consisting, again, of round-shaped fruits), with the plums in this last grouping also having the largest values of mass (33 g) and length (44 m) out of the entire population examined. On the other hand, the samples that originated from Morelos clustered inside Groups III and V - both of which contained red, oblong fruits differing in their individual values of lightness and flavor - as well in Group V, which contained fruit of a darker hue and of a higher FI (31). Lastly, the yellow-orange fruits from Guerrero clustered inside Groups I and VI, which differed in terms of mass (15 and $11.2 \mathrm{~g}$ ), TSS content (11.7 and $10.9^{\circ}$ Brix) and FI values (19.1 and 14.3), whereas red-colored fruits from the same region clustered instead inside groups III, IV (round-shaped) and V.

Furthermore, in a 30 -unit sample of $S$. purpurea fruit from Guatemala, Otzoy et al. (2005) reported the formation of three different groups. In the first group includes three jocotes de corona (small, intermediate and big), at the second group, one big jocote de corona and one purple jocote, in the third group the rest of population was included. On the other hand, using 10 quantitative traits and Ward's method, Pinto et al. (2003) produced 4 different groupings from 30 genotypes of S. mombin originating from Brazil. The first group consisted of nine accessions that had the greatest values of epicarp mass (11.69-16.08 g) and an average industrial yield (3.65-6.9\%); the second cluster consisted of 8 genotypes with the lowest content of TSS (7.07$13^{\circ}$ Brix) and total sugars (5.78-11.30); the third group consisted of 2 genotypes with the lowest pulp mass ( 6.2 and $11.9 \mathrm{~g})$ and industrial yield (2.72 and $3.81 \%$ ); the fourth group had the highest number of accessions (11) and consisted of genotypes with the highest mass (8.5-18 g) and pulp yield (6.05-7.76\%).

Using principal component analysis, Pinto et al. (2003) determined that the second component explained $80.92 \%$ of the variation present in the fruits of $S$. mombin, and that the characters contributing the most to the formation of the different groupings were pulp and epicarp mass, TSS content, total sugars, and industrial yield. At the same time, Otzoy et al. (2005) reported that juiciness, flavor, TSS and fruit mass are 
also variables that contribute to the separation of $S$. purpurea groups in fruits from Guatemala. In this study, canonical discriminant analysis confirmed the results obtained from cluster analysis, wherein the separation of groups was largely based on the length, flavor, and color components. Similar results were reported by Alia et al. (2012) using the UPGMA method.

Furthermore, the morphological differences that exist between wild and cultivated populations of $S$. purpurea point to the occurrence of genetic changes during the process of domestication and selection, probably as a result of the emergence of new alleles or of the disappearance of wild-type genes due to the extinction of tropical dry forests (MILLER et al., 2006). Neto et al. (2013) during the examination and comparison of two rural communities of brazil regarding the knowledge, perception of morphological variations (size fruit, flavor fruit, shape fruit, yield pulp and fruit color), morphological characteristics of preference at the time of collection; evaluation on the inter- and intrapopulation morphological differences of species and assessment of diversity, variability and local genetic structure of Spondias tuberosa populations under different management regimes based on the ISSR analysis. Pointed to the maintenance of local genetic and morphological diversity, being it strongly related to the management practices of the species, especially the $S$. tuberosa tolerance in open areas for farming and pasture. These differences have also been highlighted by other authors such as Ramirez et al. (2008) and Ruenes et al. (2010) who mention that fruit quality of $S$. purpurea depends both on the physical and morphological characteristics of the fruit as well as in its chemical composition, which ultimately leads to differences in the preferences of consumers. Thus, artificial selection may have been responsible for the observed differences among $S$. purpurea ecotypes, where cultivated varieties usually produce fruit with the best commercial attributes (diversity of colors, sweet flavors, and larger sizes) compared to wild populations (red or yellow color, acidic flavors, and smaller sizes).

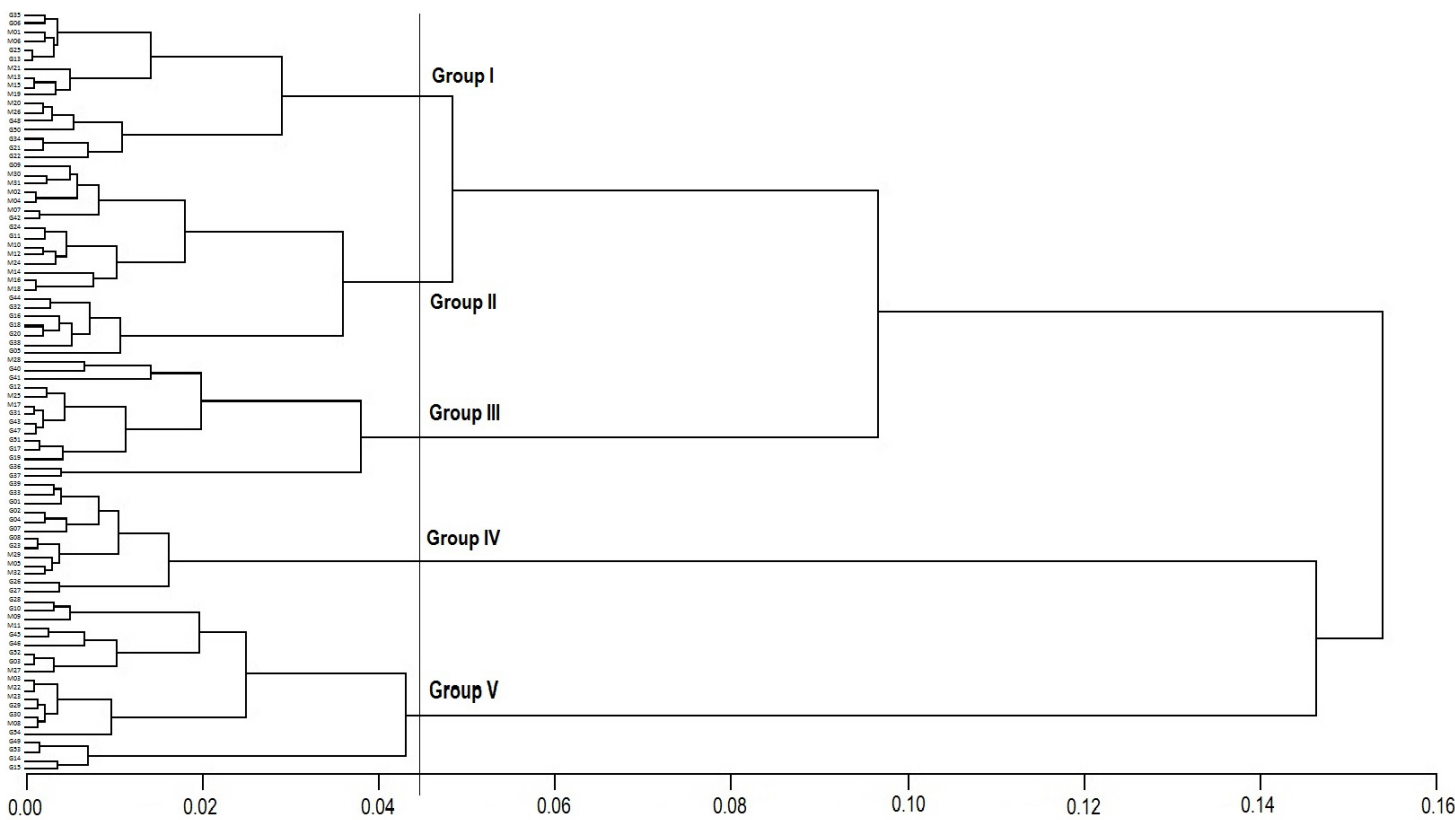

FIGURE 1-Dendrogram of 86 accessions of $S$. purpurea in the states of Guerrero and Morelos considering 16 physicochemical characters. 
TABLE 1-Ecotypes of Mexican plum evaluated and the geographic coordinates of each sampling location.

\begin{tabular}{|c|c|c|c|c|c|c|c|}
\hline \multirow{2}{*}{$\begin{array}{l}\text { Ecotype } \\
\text { ID code }\end{array}$} & \multicolumn{2}{|c|}{ Sampling location } & \multicolumn{2}{|c|}{ Coordinates } & \multirow{2}{*}{$\begin{array}{c}\text { Altitude } \\
\text { (m) }\end{array}$} & \multirow{2}{*}{$\begin{array}{l}\text { Temp } \\
\left({ }^{\circ} \mathrm{C}\right)\end{array}$} & \multirow{2}{*}{$\begin{array}{l}\mathrm{RH} \\
(\%)\end{array}$} \\
\hline & State & Municipality & LN & LW & & & \\
\hline$\overline{\mathrm{G} 01 *}$ & Guerrero & Acapulco & $17^{\circ} 1^{\prime} 38.3^{\prime \prime}$ & $99^{\circ} 38^{\prime} 47.6^{\prime \prime}$ & 250 & 25.7 & 84 \\
\hline G02-G03 & Guerrero & Acapulco & $16^{\circ} 58^{\prime} 10.7 "$ & $99^{\circ} 48^{\prime} 39.9 \prime \prime$ & 121 & 35 & 47 \\
\hline G04 & Guerrero & Acapulco & $17^{\circ} 1 ' 11.9 '$ & $99^{\circ} 47^{\prime} 25.7^{\prime \prime}$ & 311 & 35 & 49 \\
\hline G05-G06 & Guerrero & Acapulco & $17^{\circ} 4^{\prime} 37^{\prime \prime}$ & $99^{\circ} 44^{\prime} 28.9^{\prime \prime}$ & 480 & 33.3 & 50 \\
\hline G07-G08* & Guerrero & Acapulco & $17^{\circ} 4^{\prime} 37.2^{\prime \prime}$ & $99^{\circ} 44^{\prime} 28.2^{\prime \prime}$ & 468 & 33.3 & 50 \\
\hline G09 & Guerrero & Acapulco & $17^{\circ} 7^{\prime} 2.61^{\prime \prime}$ & $99^{\circ} 41^{\prime} 58.1^{\prime \prime}$ & 488 & 34 & 50 \\
\hline G10-G12 & Guerrero & Buena vista & $18^{\circ} 32^{\prime} 21.7^{\prime \prime}$ & $99^{\circ} 26^{\prime} 24.9^{\prime \prime}$ & 1229 & 33.4 & 30 \\
\hline G13 & Guerrero & Buena vista & $18^{\circ} 32^{\prime} 42.1^{\prime \prime}$ & $99^{\circ} 25^{\prime} 59^{\prime \prime}$ & 1123 & 33.5 & 36 \\
\hline G14-G15* & Guerrero & Cocula & $18^{\circ} 14^{\prime} 11.9$ ' & $99^{\circ} 42^{\prime} 53.8^{\prime \prime}$ & 947 & 32 & 35 \\
\hline G16-G17 & Guerrero & Cocula & $18^{\circ} 13^{\prime} 18.7^{\prime \prime}$ & $99^{\circ} 43^{\prime} 18^{\prime \prime}$ & 1001 & 31.6 & 44 \\
\hline G18-G20 & Guerrero & Cocula & $18^{\circ} 14^{\prime} 1.42^{\prime \prime}$ & $99^{\circ} 39^{\prime} 17.8^{\prime \prime}$ & 626 & 36 & 30 \\
\hline $\mathrm{G} 21-\mathrm{G} 22$ & Guerrero & Cocula & $18^{\circ} 14^{\prime} 17.9^{\prime \prime}$ & $99^{\circ} 39^{\prime} 33.1$ ', & 633 & 36 & 28 \\
\hline $\mathrm{G} 23 *$ & Guerrero & Chilpancingo & $17^{\circ} 24^{\prime} 27.4^{\prime \prime}$ & $99^{\circ} 27^{\prime} 58.5^{\prime \prime}$ & 1200 & 32 & 50 \\
\hline G24-G26 & Guerrero & Huitzuco & $18^{\circ} 21^{\prime} 14.7$ '" & $99^{\circ} 24^{\prime} 52.3^{\prime \prime}$ & 882 & 41.2 & $<20$ \\
\hline $\mathrm{G} 27^{*}$ & Guerrero & Iguala & $18^{\circ} 23^{\prime} 29.5^{\prime \prime}$ & $99^{\circ} 30^{\prime} 15.4$ ' & 904 & 35.5 & 30 \\
\hline G28-G29* & Guerrero & Iguala & $18^{\circ} 23^{\prime} 35.4^{\prime \prime}$ & $99^{\circ} 29^{\prime} 37.3 "$ & 950 & 37.6 & 24 \\
\hline $\mathrm{G} 30 *$ & Guerrero & Iguala & $18^{\circ} 23^{\prime} 6.6{ }^{\prime \prime}$ & $99^{\circ} 29^{\prime} 36.3 "$ & 1049 & 38.8 & $<20$ \\
\hline G31 & Guerrero & Iguala & $18^{\circ} 19^{\prime} 58.5^{\prime \prime}$ & $99^{\circ} 31^{\prime} 17.7^{\prime \prime}$ & 811 & 34 & 30 \\
\hline G32 & Guerrero & Iguala & $18^{\circ} 15^{\prime} 15.6^{\prime \prime}$ & $99^{\circ} 31^{\prime} 33.8^{\prime \prime}$ & 894 & 42 & $<20$ \\
\hline $\mathrm{G} 33 *$ & Guerrero & Juan R. E. & $17^{\circ} 10^{\prime} 57.5^{\prime \prime}$ & $99^{\circ} 31^{\prime} 1.3 "$ & 385 & 33 & 30 \\
\hline G34 & Guerrero & Taxco & $18^{\circ} 28^{\prime} 38.2^{\prime \prime}$ & $99^{\circ} 34^{\prime} 54.8{ }^{\prime \prime}$ & 1244 & 30 & 50 \\
\hline G35-G36 & Guerrero & Teloloapan & $18^{\circ} 20^{\prime} 58.9^{\prime \prime}$ & $99^{\circ} 40^{\prime} 54.6{ }^{\prime \prime}$ & 824 & 42 & 27 \\
\hline G37-G38 & Guerrero & Teloloapan & $18^{\circ} 21^{\prime} 1.2$ '" & $99^{\circ} 40^{\prime} 53.1 "$ & 834 & 42 & 27 \\
\hline G39 & Guerrero & Teloloapan & $18^{\circ} 20^{\prime} 16.4^{\prime \prime}$ & $99^{\circ} 42^{\prime} 7.8 \prime$ & 1043 & 38 & 31 \\
\hline G4-G41 & Guerrero & Tepecoacuilco & $18^{\circ} 17^{\prime} 47.9^{\prime \prime}$ & $99^{\circ} 27^{\prime} 28.4^{\prime \prime}$ & 855 & 36.5 & 24 \\
\hline G42 & Guerrero & Tepecos & $18^{\circ} 17^{\prime} 56.2^{\prime \prime}$ & $99^{\circ} 26^{\prime} 13.5^{\prime \prime}$ & 881 & 38.5 & 20 \\
\hline G43 & Guerrero & Tepeco & '17059'57.7' & $99^{\circ} 32^{\prime} 36.6^{\prime \prime}$ & 567 & 40.1 & 50 \\
\hline G44-G48 & Guerrero & Tepe & $18^{\circ} 5^{\prime} 48.7^{\prime \prime}$ & $99^{\circ} 33^{\prime} 42.6^{\prime \prime}$ & 750 & 40 & $<20$ \\
\hline G49* & Guerrero & Tepeco & $18^{\circ} 8^{\prime} 17^{\prime \prime}$ & $99^{\circ} 33^{\prime} 12.8^{\prime \prime}$ & 738 & 37.9 & 24 \\
\hline G50 & Guerrero & Tepe & י'י7'29.9' & $99^{\circ} 33^{\prime} 4.09^{\prime \prime}$ & 759 & 41.1 & 20 \\
\hline G51-G52 & Guerrero & Tep & $18^{\circ} 9^{\prime} 42.1^{\prime \prime}$ & $99^{\circ} 33^{\prime} 6.72^{\prime \prime}$ & 7.66 & 38.7 & 24 \\
\hline G53* & Guerrero & Tepec & $18^{\circ} 11^{\prime} 58^{\prime \prime}$ & $99^{\circ} 32^{\prime} 20.8^{\prime \prime}$ & 929 & 38.8 & 24 \\
\hline G54* & Guerrero & Zump & $18^{\circ} 41^{\prime} 8.5^{\prime \prime}$ & $99^{\circ} 32^{\prime} 6.33^{\prime \prime}$ & 977 & 40.5 & 22 \\
\hline M01-M02 & Morelos & Axochi & $18^{\circ} 27^{\prime} 38.4^{\prime \prime}$ & $98^{\circ} 43^{\prime} 17.2^{\prime \prime}$ & 1015 & 40 & $<20$ \\
\hline M03* & Morelos & Axochiapan & $18^{\circ} 27^{\prime} 52.5^{\prime \prime}$ & $98^{\circ} 43^{\prime} 28^{\prime \prime}$ & 1009 & 40 & $<20$ \\
\hline M04 & Morelos & Axochiapan & $18^{\circ} 28^{\prime} 0.2^{\prime \prime}$ & $98^{\circ} 43^{\prime} 34.7^{\prime \prime}$ & 1016 & 36.8 & $<20$ \\
\hline M05 & Morelos & Axochiapan & $18^{\circ} 29^{\prime} 4.7$ & $98^{\circ} 44^{\prime} 28.1$ & 1026 & 38.8 & $<20$ \\
\hline M06-M07 & Morelos & Axochiapan & 18०33'21.9' & $98^{\circ} 46^{\prime} 34.2$ & 1105 & 35.1 & $<20$ \\
\hline M08-M09* & Morelos & lán del rio & $18^{\circ} 45^{\prime} 35.5^{\prime \prime}$ & $99^{\circ} 27^{\prime} 29^{\prime \prime}$ & 1062 & 35.5 & $<20$ \\
\hline M10-M11 & Morelos & Coatlán del rio & $18^{\circ} 45^{\prime} 28.3^{\prime \prime}$ & $99^{\circ} 27^{\prime} 28.6^{\prime \prime}$ & 1059 & 38.5 & $<20$ \\
\hline M12 & Morelos & Coatlán del rio & $18^{\circ} 45^{\prime} 18.1 "$ & $99^{\circ} 27^{\prime} 16.9$ ' & 1057 & 38.8 & $<20$ \\
\hline M13* & Morelos & Jojutla & $18^{\circ} 36^{\prime} 52.9^{\prime \prime}$ & $99^{\circ} 12^{\prime} 45.9$ ' & 940 & 25.7 & 74 \\
\hline M14-M18 & Morelos & Jojutla & $18^{\circ} 36^{\prime} 56.1^{\prime \prime}$ & $99^{\circ} 12^{\prime} 46^{\prime \prime}$ & 932 & 25.7 & 74 \\
\hline M19-M20 & Morelos & Jojutla & $18^{\circ} 34^{\prime} 24.1^{\prime \prime}$ & $99^{\circ} 15^{\prime} 51.5$ ' & 925 & 32.6 & 37 \\
\hline M21* & Morelos & Mazatepec & $18^{\circ} 40^{\prime} 15.5^{\prime \prime}$ & $99^{\circ} 22^{\prime} 31.6 "$ & 944 & 36.9 & 22 \\
\hline M22-M23* & Morelos & Tepalcingo & $18^{\circ} 37^{\prime} 51.9 '$ & $98^{\circ} 53 ' 54.6 "$ & 1199 & 36.5 & $<20$ \\
\hline M24 & Morelos & Tetecala & $18^{\circ} 43^{\prime} 26.8^{\prime \prime}$ & $99^{\circ} 24^{\prime} 20.7^{\prime \prime}$ & 1003 & 43.5 & $<20$ \\
\hline $\mathrm{M} 25$ & Morelos & Tetecala & $18^{\circ} 43^{\prime} 50.3^{\prime \prime}$ & $99^{\circ} 23^{\prime} 57.5$ & 997 & 36 & $<20$ \\
\hline M26 & Morelos & Tetecala & $18^{\circ} 41^{\prime} 59.3$ "' & $99^{\circ} 22^{\prime} 28.9^{\prime \prime}$ & 960 & 36.5 & 25 \\
\hline M27* & Morelos & Tlaltizapán & $18^{\circ} 41 ' 13.1 "$ & $99^{\circ} 9^{\prime} 1.1 "$ & 935 & 34.5 & $<20$ \\
\hline M28-M30 & Morelos & Tlaltizapán & $18^{\circ} 41^{\prime} 15.3 "$ & $99^{\circ} 7^{\prime} 1.7^{\prime \prime}$ & 952 & 32 & 24 \\
\hline M31 & & Tlaltizapán & $18^{\circ} 41^{\prime} 33.2^{\prime \prime}$ & $99^{\circ} 6^{\prime} 52.5^{\prime \prime}$ & 976 & 35.5 & $<20$ \\
\hline M32 & Morelos & Tlaltizapán & $18^{\circ} 38^{\prime} 13.3 "$ & $99^{\circ} 0{ }^{\prime} 28.2^{\prime \prime}$ & 1012 & 32.5 & 29 \\
\hline
\end{tabular}

LN: Latitude north, LW: Longitude west, RH: Relative humidity. *wild ecotypes. 
TABLE 2 - Evaluated variables and their corresponding statistical parameters in the 86 ecotypes of Mexican plum analyzed.

\begin{tabular}{lcccccc}
\hline \multicolumn{1}{c}{ Variable } & Mean & $\mathbf{S}^{\mathbf{2}}$ & $\mathbf{r}$ & Minimum & Maximum & CV (\%) \\
\hline Lightness (L*) & 41.71 & 9.38 & 49.29 & $16.51(\mathrm{G} 19)$ & $65.8(\mathrm{M} 02)$ & 22.48 \\
Chromaticity $\left(\mathrm{C}^{*}\right)$ & 36.41 & 9.10 & 59.19 & $7.60(\mathrm{G} 19)$ & $66.78(\mathrm{M} 27)$ & 24.99 \\
Hue angle (h) & 39.59 & 17.88 & 69.71 & $11.14(\mathrm{G} 19)$ & $80.84(\mathrm{M} 24)$ & 45.16 \\
Pedicel length (mm) & 6.53 & 2.29 & 15.42 & $1.25(\mathrm{M} 30)$ & $16.67(\mathrm{G} 03)$ & 35.01 \\
Fruit (mm) & 28.94 & 4.73 & 29.16 & $16.08(\mathrm{G} 53)$ & $45.24(\mathrm{G} 05)$ & 16.35 \\
Fruit shape (LD/TD) & 1.19 & 0.12 & 0.84 & $0.74(\mathrm{M} 01)$ & $1.58(\mathrm{G} 31)$ & 10.01 \\
Endocarp (mm) & 19.52 & 3.05 & 19.98 & $11.87(\mathrm{G} 53)$ & $31.85(\mathrm{M} 30)$ & 15.60 \\
Endocarp shape (LD/TD) & 1.54 & 0.23 & 1.48 & $0.81(\mathrm{M} 04)$ & $2.3(\mathrm{G} 31)$ & 15.10 \\
Fruit mass (g) & 10.87 & 5.21 & 33.0 & $3.0(\mathrm{G} 54)$ & $36.0(\mathrm{G} 05)$ & 47.93 \\
Endocarp mass (g) & 1.82 & 0.69 & 5.10 & $0.6(\mathrm{G} 15)$ & $5.7(\mathrm{G} 05)$ & 38.35 \\
Pulp yield (\%) & 65.61 & 8.44 & 49.74 & $31.91(\mathrm{G} 08)$ & $81.65(\mathrm{G} 24)$ & 12.87 \\
Firmness (N) & 2.79 & 1.08 & 7.70 & $1.2(\mathrm{G} 13)$ & $8.9(\mathrm{G} 38)$ & 38.59 \\
TSS ( ${ }^{\circ}$ Brix) & 10.89 & 2.29 & 11.0 & $6.0(\mathrm{G} 52)$ & $17.0(\mathrm{M} 25)$ & 21.08 \\
TA $(\%$ citric acid) & 0.98 & 0.59 & 2.72 & $0.33(\mathrm{G} 44)$ & $3.05(\mathrm{M} 08)$ & 60.07 \\
FI (TSS/TA) & 14.19 & 6.62 & 29.98 & $2.76(\mathrm{M} 22)$ & $32.74(\mathrm{G} 04)$ & 46.67 \\
pH & 3.23 & 0.39 & 3.05 & $1.3(\mathrm{M} 22)$ & $4.35(\mathrm{G} 04)$ & 12.31 \\
\hline
\end{tabular}

n: 1280; S²: Standard deviation; r: Range of variation; CV: Coefficient of variation; LD: Longitudinal diameter; TD: Transverse diameter; TSS: Total soluble solids; TA: Titratable acidity; FI: Flavor index.

TABLE 3 - Means of variables evaluated in the 5 groups obtained by hierarchical cluster analysis of 86 ecotypes of Mexican plum from the Mexican states of Guerrero and Morelos.

\begin{tabular}{ccccccccccccccccc}
\hline Group & L* & C* & h & PL & FL & Fs & ES & Es & FM & EM & PY & F & TSS & TA & FI & pH \\
\hline 1 & 37.8 & 34.2 & 31.7 & 6.0 & 29.6 & 1.1 & 18.2 & 1.4 & 12.2 & 1.8 & 71.7 & 2.5 & 11.2 & 0.8 & 15.8 & 3.2 \\
2 & 55.7 & 45.9 & 68.6 & 5.8 & 29.9 & 1.2 & 19.8 & 1.4 & 12.2 & 2.0 & 68.8 & 2.5 & 11.5 & 0.9 & 14.5 & 3.3 \\
3 & 33.5 & 26.4 & 27.1 & 8.1 & 33.9 & 1.2 & 21.6 & 1.8 & 16 & 2.2 & 71.9 & 4.0 & 11.5 & 0.6 & 18.3 & 3.5 \\
4 & 37.2 & 35.2 & 29.4 & 6.1 & 27.7 & 1.2 & 19.6 & 1.6 & 8.2 & 1.7 & 60.6 & 2.3 & 10.5 & 0.8 & 15.6 & 3.4 \\
5 & 41.4 & 37.4 & 35.6 & 5.3 & 23.2 & 1.3 & 17.2 & 1.5 & 5.5 & 1.3 & 59.1 & 2.9 & 9.7 & 2.1 & 4.7 & 2.7 \\
\hline
\end{tabular}

L*: Lightness (0: white; 100: black); $\mathrm{C}^{*}$ : Chromaticity; h: Hue angle $(0=$ red; $90=$ yellow); PL: Pedicel length (mm); FL: Fruit length (mm); Fs: Fruit shape; ES: Endocarp length (mm); Es: Endocarp shape; FM: Fruit mass (g); EM: endocarp mass (g); PY: Pulp Yield (\%); F: Firmness (N); TSS: Total soluble solids ( ${ }^{\circ}$ Brix); TA: Titratable acidity $(\%)$; FI: Flavor Index. Letters indicate significant differences in each variable.

TABLE 4-Eigenvalues of the canonical roots obtained using 16 physicochemical characters from the 86 ecotypes of Mexican plum evaluated.

\begin{tabular}{ccccccc}
\hline $\begin{array}{c}\text { Canonical } \\
\text { root }\end{array}$ & Eigenvalue & $\begin{array}{c}\text { Proportion of explained variance (\%) } \\
\text { Absolute }\end{array}$ & Cumulative & $\begin{array}{c}\text { Likelihood } \\
\text { ratio }\end{array}$ & $\begin{array}{c}\text { Approximate } \\
\text { F value }\end{array}$ & P $>\mathrm{F}$ \\
\hline 1 & 8.58 & 0.47 & 0.47 & 0.002 & 15.01 & $<.0001$ \\
2 & 6.48 & 0.36 & 0.83 & 0.022 & 11.45 & $<.0001$ \\
3 & 2.23 & 0.12 & 0.95 & 0.169 & 6.94 & $<.0001$ \\
4 & 0.83 & 0.05 & 1.0 & 0.547 & 4.4 & $<.0001$ \\
\hline
\end{tabular}


TABLE 5-Total canonical structure of the total variance explained by the first three canonical roots obtained using 16 quantitative traits from the 86 ecotypes of Mexican plum evaluated.

\begin{tabular}{lccc}
\hline Variables & CR1 & CR2 & CR3 \\
\hline Lightness & 0.854 & 0.434 & -0.059 \\
Chromaticity & 0.614 & 0.480 & -0.299 \\
Hue angle & 0.927 & 0.337 & 0.017 \\
Pedicel length & -0.093 & -0.485 & 0.345 \\
Fruit & 0.261 & -0.672 & 0.286 \\
Fruit shape & -0.254 & -0.046 & 0.009 \\
Endocarp & 0.126 & -0.394 & 0.166 \\
Endocarp shape & -0.275 & -0.332 & 0.263 \\
Fruit mass & 0.302 & -0.575 & 0.360 \\
Endocarp mass & 0.220 & -0.335 & 0.130 \\
Pulp yield & 0.355 & -0.500 & 0.322 \\
Firmness & -0.137 & -0.185 & 0.653 \\
TSS & 0.209 & -0.226 & 0.076 \\
TA & -0.281 & 0.815 & 0.260 \\
FI & 0.154 & -0.655 & -0.116 \\
pH & 0.137 & -0.615 & -0.130 \\
\hline
\end{tabular}

TABLE 6 -Tukey test of the canonical roots (CR) obtained from the CDA performed on the 5 groups of Mexican plum ecotypes evaluated using 16 quantitative traits.

\begin{tabular}{cccc}
\hline Group & CR1 & CR2 & CR3 \\
\hline 1 & $-0.45^{\mathrm{b}}$ & $-1.37^{\mathrm{c}}$ & $2.48^{\mathrm{a}}$ \\
2 & $5.00^{\mathrm{a}}$ & $0.90^{\mathrm{b}}$ & $1.16^{\mathrm{b}}$ \\
3 & $-1.16^{\mathrm{bc}}$ & $-3.30^{\mathrm{d}}$ & $0.052^{\mathrm{c}}$ \\
4 & $-1.83^{\mathrm{cd}}$ & $-0.58^{\mathrm{c}}$ & $-0.69^{\mathrm{c}}$ \\
5 & $-2.76^{\mathrm{d}}$ & $4.94^{\mathrm{a}}$ & $-1.77^{\mathrm{d}}$ \\
\hline
\end{tabular}

Note: letters indicate statistically significant differences (Tukey, $\alpha=0.05$ )

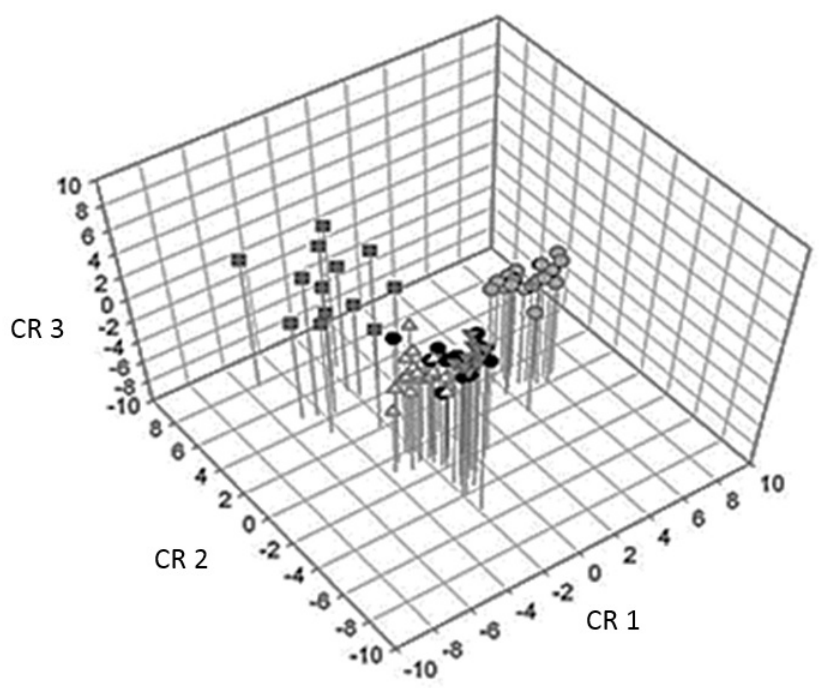

- Group 1

- Group 2

$\nabla$ Group 3

$\triangle$ Group 4

$\square$ Group 5

FIGURE 2- Tridimensional representation of the 5 groups obtained from cluster analysis of 86 accessions of $S$. purpurea in the states of Guerrero and Morelos with 16 quantitative variables. 


\section{ACKNOWLEDGEMENTS}

The authors thank to B.Sc. Leonardo Castillo Pelayo for his assistance in the revision of the English language manuscript.

We would like to thank CONACyT for the scholarship awarded to the first coauthor in support of her graduate studies. We would also like to thank SEP-PROMEP for the financial support provided for this study trough the Network "Pre and Postharvest Science and Technology”.

\section{REFERENCES}

AOAC. International Methods Committee Guidelines for validation of qualitative and quantitative food microbiological official methods of analysis. AOAC International, Washington DC. 2002. p.189.

ALIA, T.I; MALDONADO, A.Y.I; NÚÑEZ, C.C.A; VALDEZ, A.L.A; BAUTISTA, B.S; GARCÍA, V.E; ARIZA, F.R; RIVERA, C.F. Caracterización de frutos de ciruela mexicana (Spondias purpurea L.) del sur de México. Revista Fitotecnia Mexicana, Estado de México, v. 35, n.5, p.21-26, 2012.

ALMEIDA, M.M.B; SOUSA, P.H.M; ARRIAGA, A.M.C; PRADO, G.M; MAGALHÃES, C.E.C; MAIA, C.A; LEMOS, T.L.G. Bioactive compounds and antioxidant activity of fresh exotic fruits from northeastern Brazil. Food Research International, Amsterdam, v.44, n.7, p.2155-2159, 2011.

AVITIA, E.; CASTILlO, M.; PIMIENTA, E. Ciruela mexicana y otras especies del género Spondias L. México: Universidad Autónoma de Chapingo, 2000. p.90.

BOSCO, J.; SOARES, T.; AGUIAR, P.; BARROS, V. Banco ativo de germoplasma de cajá no Estado da Paraíba. In: WORKSHOP PARA CURADORES DE BANCOS DE GERMOPLASMA DE ESPÉCIES FRUTÍFERAS, 1997, Brasília, DF. Anais... Brasília, DF: Embrapa-Cenargem, 1999. p.80-85.

CHITARRA, F.; CHITARRA, B. Pós-colheita de frutos e hortaliças: fisiologia e manuseio. Lavras: ESAL/FAEPE. 2005. p.785.
DUVALL, S. On the origin of the tree Spondias mombin in Africa. Journal of Historical Geography, Texas, v.32. p.249-266. 2006.

ENGELS, C.; GRÄTER, D.; ESQUIVEL, P.; JIMÉNEZ, M.; GÄNZLE, G.; SCHIEBER, A. Characterization of phenolic compounds in jocote (Spondias purpurea L.) peels by ultra highperformance liquid chromatography/electrospray ionization mass spectrometry. Food Research International, Amsterdam, v.46, n.2, p.557-562. 2012.

FILGUEIRAS, C.; ALVES, E.; MOURA, H.; OLIVEIRA, C.; ARAÚJO, C. Calidad de frutas nativas de Latinoamerica para industria: Ciruela mexicana (Spondias purpurea L.). Proceedings of the Interamerican Society for Tropical Horticulture, San José, v.43, p.68-71. 2001.

GREGORIS, E.; PEREIRA, P.; FABRIS, S.; BERTELLE, M.; SICARI, M.; STEVANATO, R. Antioxidant Properties of Brazilian Tropical Fruits by Correlation between Different Assays. BioMed Research Internacional, New York, v.2013, p.1-8. 2013.

JOHNSON, E. Métodos multivariados aplicados al análisis de datos. México: International Thomson Editores,1998. p.566.

KOSTERMANS, H. Kedondond, ambarella, amra: the Spondiadeae (Anacardiaceae) in Asia and the Pacific Area . Bogor: Herbarium Bogoriense,1991. p.99

LIRA-JÚNIOR, D.; BEZERRA, F.; LEDERMAN, E; MOURA, M. Produção e características físicoquímicas de clones de cirigueleira na Zona da Mata Norte de Pernambuco. Revista Brasileira de Ciências Agrárias, Recife, v.5, p.43-48. 2010.

LIRA-JÚNIOR, D.; MUSSER, S.; MELO, E.; MACIEL, S.; LEDERMAN, E.; SANTOS, D. Physical and physico-chemical characterization of "Cajá-Umbu" fruits. Ciência e Tecnologia de Alimentos, Campinas, v.25, p.757-761, 2005.

LEÓN, J; SHAW, E. Spondias. The red mombin and related fruits. In: NAGY, S.; SHAW. E.; WARDOWSKI, W.F. (Ed.). Fruits of tropical and subtropical origin, composition, properties and uses. Madison: Florida Science Source, 1990. p.116-126. 
MCGUIRE, G. Reporting of objective color measurements. Horticulture Science, Amsterdam, v.27, p.1254-1255, 1992.

MACÍA, J.; BARFOD, S. Economic botany of Spondias purpurea (Anacardiaceae) in Ecuador. Economic Botany, New York, v.54, p.449-458, 2000 .

MALDONADO-ASTUDILLO,Y.; ALIATEJACAL, I.; NÚÑEZ-COLÍN, A.; JIMÉNEZHERNÁNDEZ, J.; PELAYO-ZALDÍVAR, C.; LÓPEZ-MARTÍNEZ, V.; ANDRADERODRÍGUEZ, M.; BAUTISTA-BAÑOS, S.; VALLE-GUADARRAMA, S. Postharvest physiology and technology of Spondias purpurea L. and $S$. mombin L. Scientia Horticulturae, Amsterdam, v.174. p.193-206, 2014.

MILLER, J.; KNOUFT, H. GIS-based characterization of the geographic distributions of wild and cultivated populations of the mesoamerican fruit tree Spondias purpurea (Anacardiaceae). American Journal of Botany, St Louis, v.93, p.1757-1767, 2006.

MILLER, A; SCHAAL, B. Domestication of a Mesoamerican cultivated fruit tree, Spondias purpurea. Proceedings of the National Academy of Sciences, PNAS, Washington, v.102, p.280112806, 2006.

MONGE, R.; CAMPOS, H. Tocopherol and carotenoid content of foods commonly consumed in Costa Rica. Journal of Food Composition and Analysis, San Diego, v.24, p.202-216. 2011.

MURILlo, E.; BRITTON, B.; DURANT, A. Antioxidant activity and polyphenol content in cultivated and wild edible fruits grown in Panama. Journal of Pharmacy \& Bioallied Sciences, Maryland, v.4, p.313-317. 2012.

MURILLO, E.; MELÉNDEZ, J.; PORTUGAL, F. Screening of vegetables and fruits from Panama for rich sources of Lutein and Zeaxanthin. Food Chemistry, Oxford, v.122, p.67-172. 2010.

NAVA, G.; USCANGA, B. Estudio físico y químico de doce tipos de ciruela (Spondias sp.) en el estado de Veracruz. Proceedings of Tropical Region, American Society of Horticultural Science, Ohio, v.23, p.132-136. 1979.
NETO, L.; DE OLIVEIRA, F.; BRITTO, B.; DE ALBUQUERQUE, P.Traditional knowledge, genetic and morphological diversity in populations of Spondias tuberosa Arruda (Anacardiaceae). Genetic Resources and Crop Evolution, Dordrecht, v.60, n.4, p.1389-1406. 2013.

NÚÑEZ-COLÍN, A.; ESCOBEDO-LÓPEZ, D. Caracterización de germoplasma vegetal: la piedra angular en el estudio de los recursos fitogenéticos. Acta Agrícola y Pecuaria, Cuernavaca, v.1, n.1, p.1-6. 2014.

OTZOY, R.; ALVARADO, D.; GORDILLO, L. Búsqueda, colecta, caracterización y preservación de materiales de jocote del género Spondias en la región suroccidental de Guatemala. Guatemala: Universidad de San Carlos de Guatemala, Dirección General De Investigación, 2005. p.90-93.

PÉREZ, A.; ALIA-Tejacal, I.; ANDRADE, M.; LÓPEZ, V.; PÉREZ, A.; ARIZA, R.; OTERO A.; VILLARREAL M. Características físicas y químicas de ciruelas mexicana (Spondias purpurea) en Guerrero. Revista Investigación Agropecuaria, Cuernavaca, v.5. n.2, p.141-149. 2008.

PINTO, S.; DANTAS, A.; FONSECA, O.; LEDO, S.; JESUS, C.; CALAFANGE, P.; ANDRADE, M. Caracterização física, físico-química e química de frutos de genótipos de cajazeiras. Pesquisa Agropecuaria Brasileira, Brasilia, DF, v.38, p.10591066. 2003.

POPENOE, J. The genus Spondias in Florida. Proceedings of Florida State Horticultural Society, Lake Alfred, v.92, p.277-279, 1979.

RAMÍREZ, C.; PIMIENTA, E.; CASTELLANOS, Z.; MUÑOZ, A.; PALOMINO, G.; PIMIENTA E. Sistemas de producción de Spondias purpurea (Anacardiaceae) en el centro-occidente de México. International Journal of Tropical Biology, San José, v.56, p.675-687. 2008.

RIBEIRO, B.; BONAFÉ, G.; SILVA, C.; MONTANHER, F.; SANTOS-JÚNIOR, O.; BOEING, S.; VISENTAINER, V. Antioxidant capacity, total phenolic content, fatty acids and correlation by principal component analysis of exotic and native fruits from Brazil. Journal of Brazilian Chemical Society, Campinas, v.24, p.797-804. 2013. 
RUENES, R.; CASAS, A.; JIMÉNEZ, J.; CABAllero, J. Etnobotánica de Spondias purpurea L. (Anacardiaceae) en la península de Yucatán. Interciencia, Caracas, v.35, p.247-254. 2010.

SANTOS, B.; CARDOSO, L.; FONSECA, O.; CONCEICAO, N. Characterization and quality of umbu-caja fruits (Spondias tuberosa x S. mombin) procceeding from the southern reconcavo in Bahia. Revista Brasileira de Fruticultura, Jaboticabal, v.32, n.4, p.1089-1097, 2010.

SAS Institute. SAS OnlineDoc $\AA$. Version 8. Cary: SAS Institute, 1999.
SILVA, J.; MOREIRA, G.; MELO, A.; LIMA, G. Compostos fenólicos e atividade antioxidante de ciriguelas. Alimentos e Nutrição, Araraquara, v.23, p.73-80. 2012.

VARGAS, S.G; HERNÁNDEZ, C.R; MOGUEL, O.E. Caracterización morfológica de ciruela (Spondias purpurea L.) en tres municipios del estado de Tabasco, México. Bioagro, Barquisimeto, v.23, p.141-149. 2011.

WARD, Jr. Hierarchical grouping to optimize an objective function. Journal of the American Statistical Association, Alexandria, v.58, p.236244. 1963. 